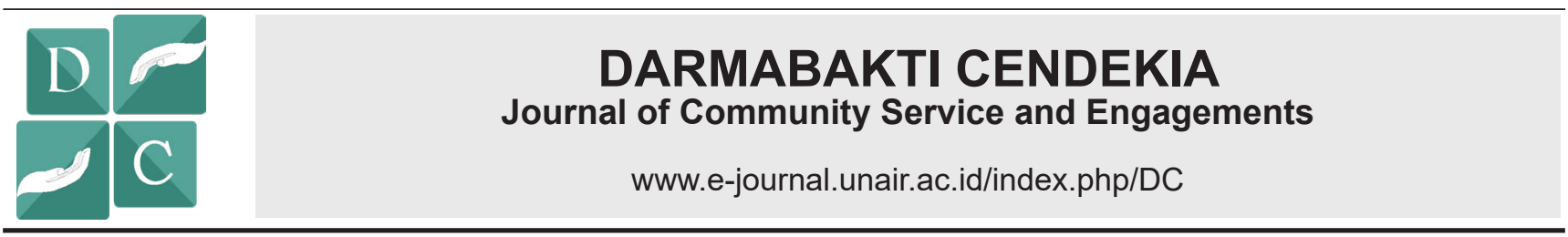

\title{
LINE FOLLOWER ROBOT TRAINING AND INTRODUCTION OF INTERNET OF THINGS (IoT) FOR STUDENTS IN JOMBANG CITY
}

\author{
PELATIHAN ROBOT LINE FOLLOWER DAN PENGENALAN \\ INTERNET OF THINGS (IoT) UNTUK SISWA DI KOTA JOMBANG
}

Scope:
Applied Sciences

\author{
Eva Inaiyah Agustin ${ }^{1 *}$, Riky Tri Yunardi ${ }^{1}$, Winarno ${ }^{2}$ \\ ${ }^{1}$ Automation of Instrumentation System, Faculty of Vocational Studies, Universitas Airlangga, Surabaya-Indonesia \\ ${ }^{2}$ Department of Physics, Faculty of Science and Technology, Universitas Airlangga, Surabaya-Indonesia
}

\begin{abstract}
A B S T R A C T
Background: During the Industrial Revolution 4.0, the Internet of Things (IOT) is the main pillar of people and machines connected to each other. It can be an intelligent system when combined with a robot. This is what underlies the importance of robotics and IoT training, especially to be introduced early on. Purpose: This activity aimed to improve students knowledge and skills in technology. The target of this activity is high school students in Jombang City. Method: It starts from the planning, implementation, and evaluation stages. Auditory, visual and kinesthetic techniques are used in this activity, which is in the form of interesting learning media such as power points, videos, as well as demonstrations and practices. Data collection techniques such as questionnaires, pretest, and post-test, and running tests were carried out to measure the level of skills, knowledge, and satisfaction of participants. Results: A total of $85 \%$ of participants did not know about IOT and $83 \%$ of the participants already know what the robot. But only $17 \%$ ever make robots. Conclusion: After this activity the participant's understanding increased by $20 \%$. Their skills also increased as evidenced by the participants programming themselves so that the robot can run well on the track.
\end{abstract}

\begin{abstract}
A B S T R A K
Latar belakang: Dalam Revolusi Industri 4.0, Internet of Things (IOT) adalah pilar utamanya manusia dan mesin dapat saling terhubung. IoT dapat menjadi sistem yang cerdas jika digabungkan dengan robot. Hal inilah yang mendasari pentingnya pelatihan robotika dan loT terutama untuk diperkenalkan sejak dini. Tujuan: Tujuan kegiatan ini adalah untuk meningkatkan pengetahuan dan keterampilan siswa dalam teknologi keduanya. Sasaran kegiatan ini adalah siswa setingkat SMA di Kota Jombang. Metode: Metode kegiatan ini dimulai dari tahap perencanaan, pelaksanaan, dan evaluasi. Teknik auditori, visual, dan kinestetik digunakan dalam kegiatan ini, yaitu berupa media pembelajaran yang menarik seperti power point, video, serta demonstrasi dan praktek. Teknik pengumpulan data seperti kuesioner, pre-test, dan post-test, serta running test dilakukan untuk mengukur tingkat keterampilan, pengetahuan, dan kepuasan peserta. Hasil: Sebanyak $85 \%$ peserta belum mengetahui tentang loT dan $83 \%$ peserta sudah tahu apa itu robot. Tetapi hanya $17 \%$ saja yang pernah membuat robot. Kesimpulan: Setelah kegiatan ini pemahaman peserta meningkat $20 \%$. Keterampilan mereka juga semakin meningkat dibuktikan dengan peserta memprogram sendiri sehingga robot dapat berjalan dengan baik pada lintasan.
\end{abstract}

\section{ART I CLE INFO}

Recieved 7 October 2019 Accepted 6 November 2019

Online 20 December 2019

*Correspondence (Korespondensi): Eva Inaiyah Agustin

E-mail: evainaiyah@gmail.com

Keywords:

Internet of Things; Robotics training; Jombang City

Kata kunci:

Internet of Things; Pelatihan robotika; Kota Jombang 


\section{PENDAHULUAN}

Perkembangan teknologi otomatisasi atau otomasi khususnya robotika berkembang sangat pesat hampir di seluruh industri termasuk di Indonesia. Sehingga pada era globalisasi saat ini yang lebih dikenal dengan Revolusi Industrikeempat atau Industri 4.0, lembaga pendidikan mulai dari Sekolah Dasar sampai Perguruan Tinggi dituntut untuk tidak hanya mampu secara teoritis tetapi juga secara praktis. Dalam Revolusi Industri 4.0, Internet of Things (IOT) adalah pilar utama karena dapat menghubungkan antara manusia dengan mesin. IoT berpengaruh pada berbagai jenis industri seperti manufaktur, otomotif, logistik, medis, tata kota, dsb (Sarhan, 2018). IoT dapat menjadi sistem yang cerdas jika digabungkan dengan perangkat keras, perangkat lunak, dan konektivitas, contohnya robot. Otomasi robotika yang diintegrasikan dengan IOT membawa peluang yang luar biasa. Hal ini akan memberikan dampak positif terhadap pertumbuhan negara karena meningkatkan ekspor, menciptakan pekerjaan berketerampilan tinggi, meningkatkan efisiensi biaya, produktivitas, dan hasil kerja yang berkualitas, serta meringankan tugas yang berat dan berulang bagi karyawan di Industri (Grammatikis et al, 2018).

Jombang adalah salah satu kota di Jawa Timur yang terhubung dengan akses jalan tol. Letaknya sangat strategis karena berada di jalur yang sering dilewati jika ingin menuju ke kota Surabaya atau menuju lintas provinsi seperti Jawa Tengah. Hal inilah yang membuat tingkat mobilitas semakin tinggi sehingga perekonomian khususnya industri di Kota Jombang juga semakin dilirik dan diperhitungkan. Beberapa industri di Kabupaten Jombang diantaranya adalah PT Pei Hai Wiratama Indonesia, PT Japfa Comfeed, PT Usmany Indah, MKS-Sampoerna, PT Cheil Jedang Indonesia, PT Mentari International, PT Seng Fong Moulding Perkasa, dan lainnya. Selain itu, Jombang juga memiliki dua pabrik gula yaitu di daerah denanyar (Jombang) dan cukir (Diwek). Pada tahun 2016, empat perusahaan besar di Jombang tutup dan 6.000 karyawan terancam di PHK. Perusahaanperusahaan tersebut adalah pabrik sepatu PT Volma dan pabrik alas kaki PT Shoei Indonesia yang berlokasi di Mojoagung serta pabrik sepatu PT Venezia Footwear di Mojowarno dan pabrik plywood PT Sejahtera Usaha Bersama di Desa/ Kecamatan Diwek. Hal ini karena perusahaan tidak kuat bertahan menghadapi krisis ekonomi global yang semakin berat (Tribunnews, 2016). Menurut Badan Pusat Statistik Kab. Jombang (2019), jumlah industri di Kabupaten Jombang semakin meningkat sampai dengan tahun 2017 seperti ditunjukkan pada Gambar 1(a). Lalu tercatat setidaknya ada 120 perusahaan besar dan sedang sampai tahun 2018.
Pada Gambar 1(b) menunjukkan bahwa semakin banyaknya Industri tersebut membuat penyerapan tenaga kerja juga semakin tinggi pada tahun 2017. Walaupun jumlah industri meningkat, namun pada akhir tahun 2018 jumlah pengangguran di Kabupaten Jombang juga meningkat hingga mencapai 34.151 orang. Menurut Kepala Dinas Tenaga Kerja Kabupaten Jombang, salah satu cara untuk mengurangi angka pengangguran adalah dengan mengadakan pelatihan-pelatihan (Nasikhuddin, 2018). Oleh sebab itu diperlukan upaya terus-menerus meningkatkan wawasan ilmu pengetahuan sejak dini, khususnya teknologi robotika dan Internet of Things (IOT). Agar tidak tertinggal jauh dengan penggunaan teknologi tersebut, maka peningkatan ilmu pengetahuan dan teknologi akan sangat bermanfaat dan berguna sebagai upaya peningkatan mutu sumber daya.

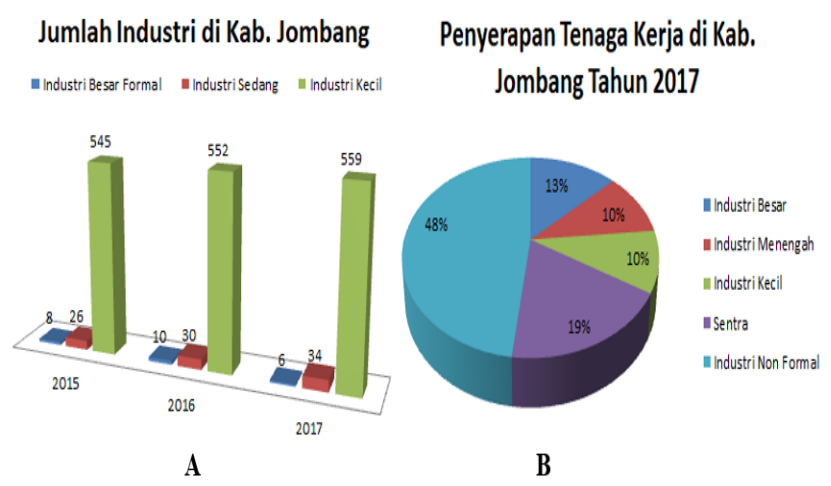

Gambar 1. (a) Jumlah industri (b) penyerapan tenaga kerja di Kabupaten Jombang.

Sumber: Dinas perindag dan Pasar Kab. Jombang (BPS Kab. Jombang, 2019), diolah.

SMK Muhammadiyah 3 Jombang adalah salah satu sekolah setingkat SMA (Sekolah Menengah Atas) di Kota Jombang yang memiliki jurusan Teknik yaitu jurusan Teknologi Komputer dan Jaringan (TKJ). Sekolah ini juga memiliki ekstrakurikuler baru yang dibuka sejak pertengahan september tahun 2018 yaitu ekstrakurikuler Robotika. Ekstrakurikuler ini merupakan wadah bagi siswa yang memiliki niat dan minat untuk belajar robotika. Menurut kepala Sekolah SMK Muhammadiyah 3 Jombang, hanya beberapa siswa saja yang tertarik untuk bergabung di ekstrakurikuler robotika tersebut. Selain itu materi robot yang diajarkan masih berupa robot analog. Padahal sistem otomasi saat ini juga mengharuskan robot untuk dapat bekerja secara digital karena ruang kerjanya mudah dikonfigurasi ulang untuk berbagai kebutuhan dan melakukan pemrosesan. Banyak faktor yang mempengaruhi seorang siswa untuk tidak dapat mempelajari ilmu pengetahuan seperti Robotika dan IoT. Salah satunya adalah faktor biaya. Belajar teknologi robotika dan IoT dapat dikatakan tidak murah. 
Tidak banyak sekolah setingkat SMA dan atau SMK (Sekolah Menengah Kejuruan) yang mengadakan pelatihan di bidang teknologi tersebut.

Oleh karena itu dibuatlah kegiatan pengabdian kepada masyarakat ini dengan tema pelatihan robotika dan pengenalan teknologi IoT yang bertempat di SMK Muhammadiyah 3 Jombang. Pelatihan robotika dalam kegiatan ini adalah pembuatan robot Line Follower secara digital yaitu menggunakan perangkat keras berupa mikrokontroler beserta pemrogramannya. Mikrokontroler yang digunakan adalah produk Arduino Uno karena selain open source, pemrogamannya juga sangat mudah dan sederhana. Dengan adanya kegiatan ini diharapkan dapat meningkatkan pengetahuan serta menumbuhkan ketertarikan siswa terhadap teknologi elektronik khususnya robotika dan IoT.

\section{METODE}

Pada kegiatan Pengabdian Masyarakat ini, sasaran yang dituju adalah siswa Sekolah Menengah khususnya di SMK Muhammadiyah 3 Jombang, Jawa Timur. Secara umum, siswa di SMK tersebut sudah mengenal teknologi komputer karena terdapat jurusan Teknologi Komputer dan Jaringan. Namun keminatan pada robotika masih sangat minim. Hal ini dapat dilihat dari pembukaan ekstrakurikuler baru pada tahun 2018 lalu yaitu ekstrakurikuler robotika yang anggotanya hanya beberapa orang saja. Oleh karena itu diharapkan dengan adanya pelatihan ini maka semakin banyak siswa yang tertarik dan mengenal robotika bahkan mampu mendemonstrasikannya.

Pelaksanaan kegiatan ini dilaksanakan dalam tiga tahap, yaitu tahap persiapan, pelaksanaan, dan evaluasi. Tahap pertama adalah tahap persiapan. Pada tahap ini, tim pelaksana melakukan survey untuk mengetahui kondisi di tempat mitra baik dari kondisi tempat yang akan digunakan untuk pelatihan maupun kondisi peserta yang akan diberikan pelatihan. Setelah melakukan survey, tim mempersiapkan alat dan bahan yang diperlukan seperti perangkat keras/ komponen perakitan robot, keperluan administrasi dan publikasi, menyusun modul kegiatan pelatihan seperti pada Gambar 2, serta presentasi kegiatan pelatihan.

Tahap kedua adalah tahap pelaksanaan. Kegiatan ini diawali dengan pembukaan di Aula SMK Muhammadiyah 3 Jombang. Setelah itu peserta diarahkan menuju ke ruang Laboratorium Komputer untuk diberikan pelatihan. Pertamatama, peserta diberikan materi tentang Internet of Things (IoT) serta terdapat demonstrasi robot yang dapat dijalankan dengan menggunakan smartphone. Setelah itu dilanjut ke materi berikutnya yaitu tentang Pengantar Robotika secara umum dan Pengantar Line Follower Robot secara khusus. Materi yang terakhir adalah pelatihan robot itu sendiri. Di akhir kegiatan, peserta diberikan kesempatan untuk mencoba robot yang telah mereka buat pada lintasan khusus apakah dapat berjalan sesuai yang diharapkan atau tidak. Dalam penyampaian keseluruhan materi, digunakan teknik auditori, visual, serta kinestetik. Teknik auditori didapatkan dari peserta mendengarkan dengan seksama terhadap materi yang dilakukan. Teknik auditori dan visual didapatkan dari media presentasi berupa power point yang menarik, video tentang robot, serta demonstrasi robot yang terhubung dengan smartphone. Teknik kinestetik didapatkan dari peserta yang ikut mencoba menjalankan robot dengan smartphone serta saat proses pelatihan membuat robot itu sendiri. Karena mereka berinteraksi langsung dengan mekanik robot dan komputer untuk pemrogaman robot. Tahap ketiga adalah tahap evaluasi. Evaluasi dilakukan setelah selesai kegiatan yang didapatkan dari peserta mengisi form pre-test (sebelum pelatihan), posttest (setelah pelatihan), dan kuesioner kepuasan seperti pada Gambar 3 dimana Skor 1 : Sangat tidak memuaskan; Skor 2 : Tidak memuaskan; Skor 3 : Biasa-biasa saja; Skor 4 : Memuaskan; dan Skor 5 : Sangat memuaskan, serta wawancara kepada mitra.

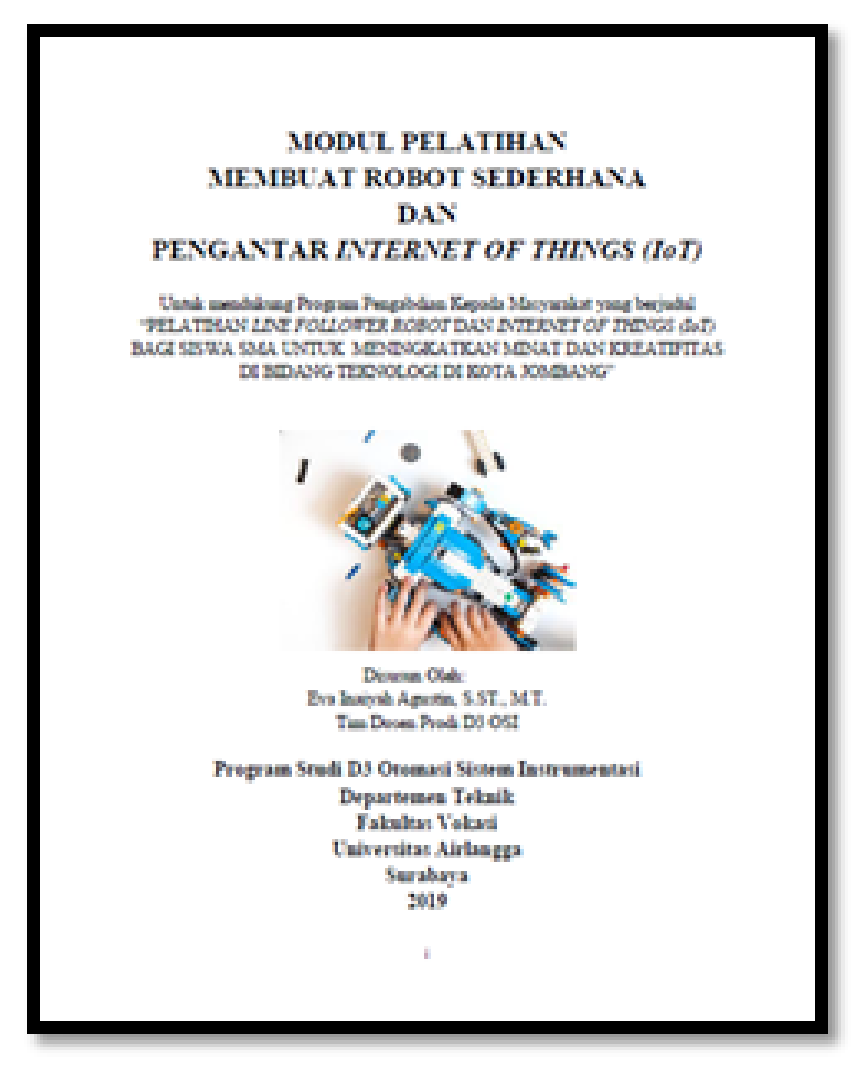

Gambar 2. Tampilan modul pelatihan. 


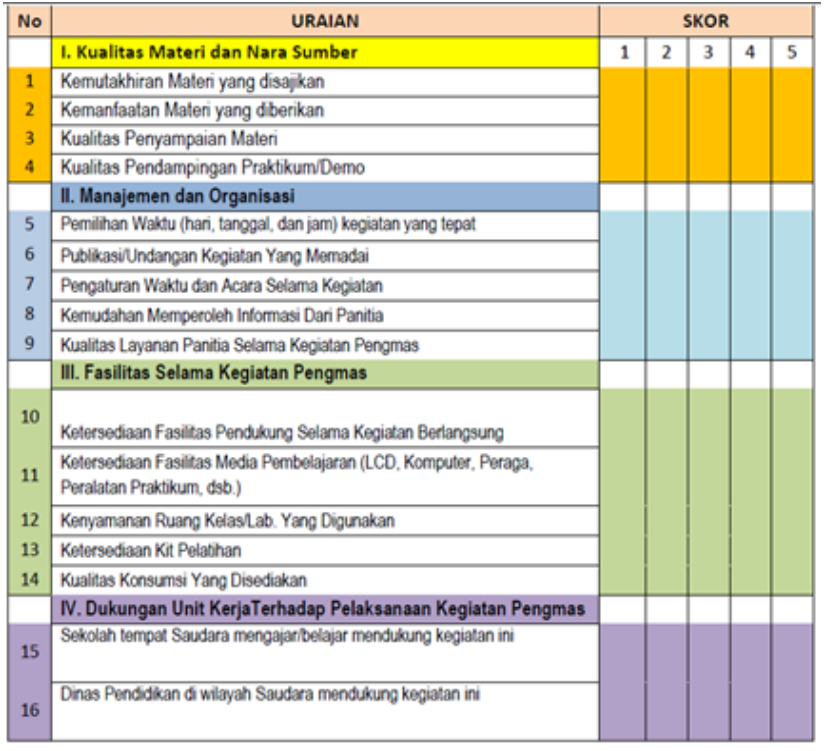

Gambar 3. Tampilan kuesioner kepuasan.

\section{HASIL DAN PEMBAHASAN}

Tahap awal dalam kegiatan Pengabdian Masyarakat adalah survey lokasi dan analisis permasalahan mitra yang dilaksanakan pada tanggal 17 Juli 2019. Robot yang akan dilatihkan adalah robot Line Follower. Robot ini dipilih karena dapat digunakan pada proses otomasi baik di bidang industri maupun di bidang kesehatan seperti di rumah sakit (Punetha et al, 2013). Robot ini secara otomatis dapat mengikuti garis. Secara umum robot mengikuti garis hitam pada permukan putih atau mengikuti garis putih pada permukaan hitam (Pakdaman \& Sanaatiyan, 2009); pathak et al, 2017; Hossain et al, 2017; Myint \& Soe, 2018). Sebelum pelaksanaan, tim pelaksana merancang hardware robot yang terdiri dari deret sensor inframerah yang diletakkan di depan robot bagian bawah (Pakdaman \& Sanaatiyan, 2009) yang berfungsi sebagai mata robot, Mekanik berupa roda dan bodi robot, baterai, serta motor sebagai penggerak robot. Mikrokontroler Arduino Uno digunakan sebagai prosesor utama atau diistilahkan sebagai otak robot.

Pada tahap pelaksanaan, Pelatihan robot Line Follower dan Pengenalan IoT dilaksanakan di Laboratorium Komputer SMK Muhammadiyah 3 Jombang, Jalan Raya Janti No. 16, Mojoagung, Jombang, Jawa Timur pada tanggal 24 Agustus 2019. Gambar 4 adalah tim beserta tim pengabdian masyarakat. Serangkaian kegiatan pelatihan dimulai dari jam 08.00 - 14.40 WIB. Narasumber pelatihan terdiri atas 4 orang dosen yang dibantu oleh dua orang mahasiswa dan 3 orang dosen sebagai asisten pelatihan serta 1 orang asisten administrasi. Jumlah peserta keseluruhan adalah 30 orang dan didampingi 2 orang guru pembina ekstrakurikuler robotika. 28 peserta berasal dari jurusan Teknologi Komputer dan Jaringan dan 2 peserta berasal dari jurusan Akuntansi.

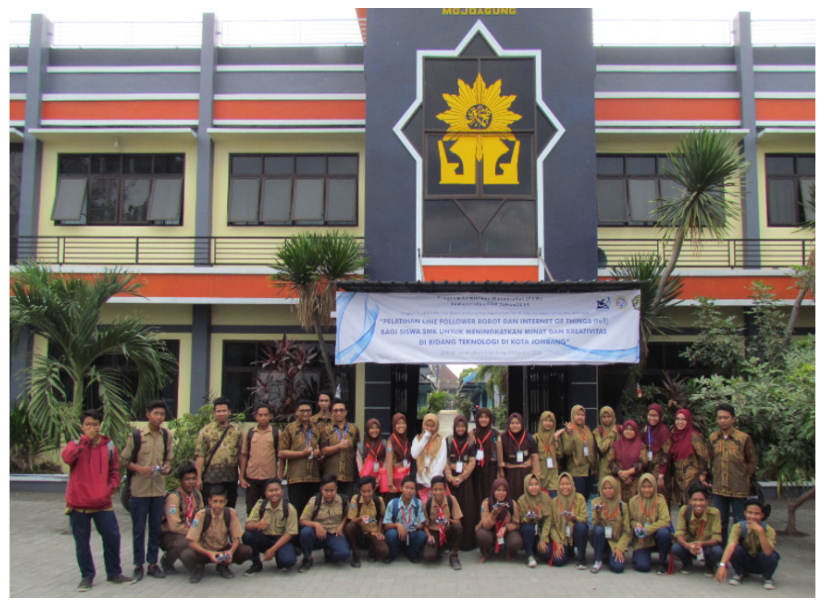

Gambar 4. Tim Pengabdian Masyarakat Universitas Airlangga dan peserta pelatihan SMK Muhammadiyah 3 Jombang.

\section{A. Pemahaman awal tentang Robotika dan Internet of Things}

Pada kegiatan pengabdian masyarakat ini, sebelum materi dimulai peserta mengisi form kuesioner awal yang berkaitan tentang gambaran awal robot dan Internet of Things. Hasil pengisian kuesioner oleh para peserta disajikan seperti pada Gambar 5 dan Gambar 6.

\section{Apakah Anda Tahu Internet of Things?}

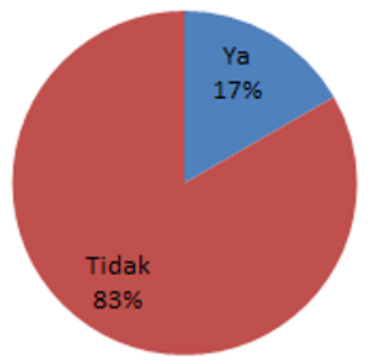

Gambar 5. Pemahaman awal terhadap Internet of Things.

Pada Gambar 5 dapat diketahui bahwa mayoritas peserta tidak mengetahui tentang Internet of Things yaitu sebesar $85 \%$ peserta. Pada Gambar 6a dan Gambar 6d dapat juga diketahui bahwa mayoritas peserta tahu tentang apa itu robot yaitu sebesar $83 \%$ tetapi hanya $17 \%$ saja yang pernah membuat robot. Rata-rata peserta semua pernah menjumpai robot dan 53\% paling besar adalah di sekolah, sedangkan sisanya adalah di toko mainan, Televisi (TV), Internet, dan lain-lain. 


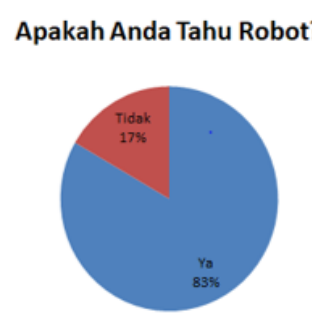

(a)

\section{Dimana Anda Melihat Robot}

" Sekolah " $=$ Toko Mainan $=$ TV = Internet =

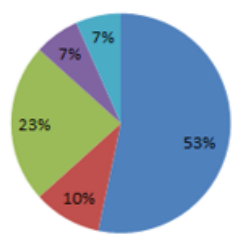

(c)

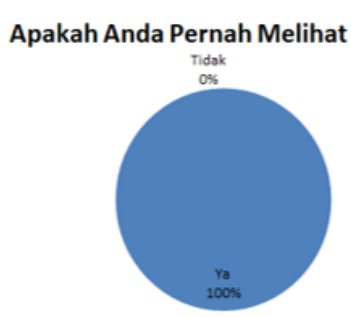

(b)

\begin{abstract}
Apakah Anda Pernah Membuat Robot?
\end{abstract}

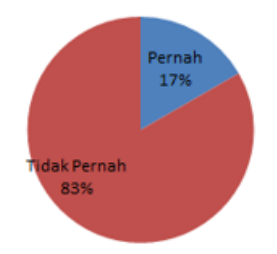

(d)
Gambar 6. Pemahaman awal tentang robot.

\section{B. Pemahaman Pengetahuan Tentang Robotika dan Internet of Things}

Kegiatan pengabdian ini memiliki tujuan yaitu untuk dapat meningkatkan pengetahuan siswa terkait teknologi robotika dan Internet of Things. Untuk mengukur tingkat pengetahuan siswa, maka siswa diberi kesempatan untuk menjawab soal yang sama yang dikerjakan saat sebelum pelatihan (pretest) dan saat setelah pelatihan (post-test). Setiap siswa mengerjakan 10 soal yang dikerjakan selama kurang lebih 15 menit. Dari hasil menjawab soal tersebut dapat diketahui bahwa ada peningkatan pengetahuan siswa. Hal ini ditunjukkan pada Gambar 7 yaitu saat pre-test, dari 10 soal yang diberikan maka siswa rata-rata menjawab 5 soal benar. Dan pada saat post test, siswa rata-rata mampu menjawab 7 soal benar.

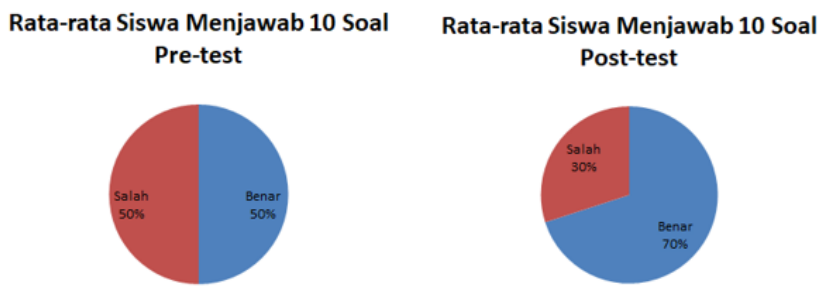

Gambar 7. Rata-rata peningkatan pengetahuan siswa.

\section{Pemrogaman Line Follower Robot}

Pada tahapan pembuatan Line Follower Robot, siswa tidak dituntut untuk merangkai mekanik dan perangkat keras robot. Namun siswa diharapkan mampu untuk memprogram atau mengaturjalannya robot agar dapat berjalan dengan baik/ tidak keluar jalur pada sebuah lintasan khusus. Perangkat lunak yang digunakan untuk memprogram robot adalah IDE Arduino menggunakan bahasa C. Pada Gambar 8 berikut adalah robot yang diprogram beserta lintasan robot.

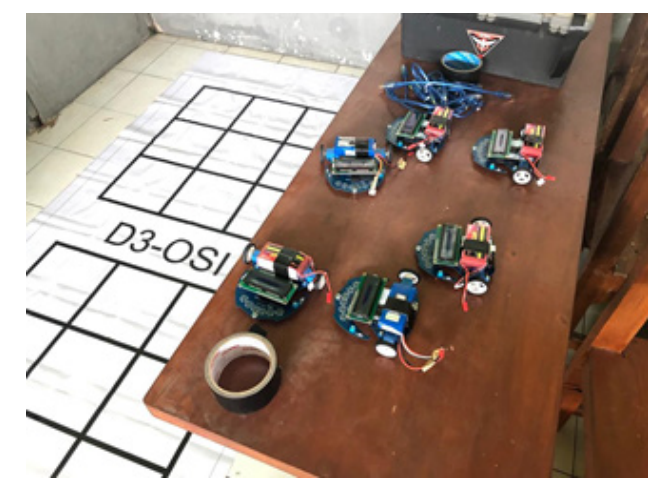

Gambar 8. Line follower robot beserta lintasan robot.

\section{Tingkat Kepuasan Peserta}

Tahap evaluasi yang lain adalah siswa mengisi form kuesioner kepuasan terhadap kegiatan pelaksanaan pengabdian masyarakat. Ada 16 aspek yang ditanyakan seperti pada Gambar 3. Dari banyak aspek tersebut, aspek tertinggi adalah pada aspek kemanfaatan materi yang diberikan, kualitas konsumsi yang disediakan, serta Sekolah yang sangat mendukung kegiatan ini dengan skor 4,5. Untuk skor terendah yaitu 4,0 adalah aspek kenyamanan ruang kelas yang digunakan. Hal ini karena salah satu faktornya adalah di dalam Lab. Komputer hanya terdapat kipas angin dan tidak terdapat pendingin ruangan (Air Conditioner).

\section{KESIMPULAN DAN SARAN}

Pengabdian kepada masyarakat dengan tema pelatihan robotika dan pengenalan Internet of Things yang telah dilaksanakan kepada mitra berjalan dengan baik serta siswa dapat mengikuti pelatihan pemrogaman robot Line Follower dengan senang dan antusias. Serangkaian kegiatan pelatihan ini juga dapat meningkatkan pengetahuan dan keterampilan siswa khususnya siswa SMK Muhammadiyah 3 Jombang.

Dalam kegiatan ini semua komponen sudah diletakkan didalam mekanik robot sehingga siswa kesulitan mengenali detail bagian-bagiannya. Saran untuk tim pengabdian masyarakat selanjutnya yaitu pada tahap awal pelatihan ditunjukkan lebih detail komponen-komponen utama yang diletakkan pada robot seperti sensor sebagai mata robot, mikrokontroler sebagai otak robot, dan sebagainya. Sehingga diharapkan siswa semakin memahami perangkat keras dan perangkat lunak robot. 


\section{UCAPAN TERIMA KASIH}

Penulis mengucapkan terimakasih kepada Direktorat Jenderal Pendidikan Tinggi Indonesia yang telah mendanai kegiatan Pengabdian Masyarakat ini dengan skema Program Kemitraan Masyarakat (PKM) Tahun 2019. Ucapan terimakasih juga disampaikan kepada Lembaga Pengabdian Masyarakat Universitas Airlangga, Fakultas Vokasi Universitas Airlangga, Program Studi Otomasi Sistem Instrumentasi Universitas Airlangga, serta SMK Muhammadiyah 3 Jombang sebagai Mitra dalam kegiatan ini. Penulis menyatakan tidak ada konflik kepentingan dengan pihak-pihak yang terkait dalam kegiatan pengabdian kepada masyarakat ini.

\section{DAFTAR PUSTAKA}

Badan Pusat Statistik Kabupaten Jombang. 2019. Available from: https://jombangkab.bps.go.id/. Diakses 4 Oktober 2010.

Grammatikis, P.I.R., Sarigiannidis, P.G., Moscholios, I.D. 2018. Securing the Internet of Things: challenges, threats and solutions. Internet of Things.

Hossain, M.I., Islam, S.M.R., Rahman, M.M., Quamrul, H.A.S.M. 2017. Novel Design for the Autonomous Line Follower Robot Using Microcontroller PIC16F676. Journal of Electrical Engineering \& Electronic Technology Vol. 6(1). Pp 1-3.

Myint, M.M., Soe, N.K. 2018. Line Follower Robot Using Line Tracing Sensors. International Journal of Science, Engineering and Technology Research (IJSETR) Vol. 7(8). Pp 561-563.

Nasikhuddin. 2019. Terus Naik, Jumlah Pengangguran di Jombang Capai 34.151 Orang. Available from: https://radarjombang.jawapos. com/read/2018/11/21/104671/terus-naik-jumlahpengangguran-di-jombang-capai-34151-orang. Diakses 4 Oktober 2019.

Pakdaman, M., Sanaatiyan, M.M. 2009. Design and implementation of line follower robot. In 2009 Second International Conference on Computer and Electrical Engineering Vol. 2. Pp 585-590.

Pathak, A., Pathan, R.K., Tutul, A.U., Tousi, N.T., Rubaba, A.S., Bithi, N.Y. 2017. Line follower robot for industrial manufacturing process. International Journal of Engineering Inventions Vol. 6(10). Pp 10-17.

Punetha, D., Kumar, N., Mehta, V.2013. Development and applications of line following robot based health care management system. International Journal of Advanced Research in Computer Engineering \& Technology (IJARCET) Vol. 2(8). Pp 2446-2450.
Sarhan, Q.I. 2018. Internet of things: a survey of challenges and issues. International Journal of Internet of Things and Cyber-Assurance Vol.1(1). Pp 40-75.

Sutono, Yuli. 2015. Perusahaan Korea Selatan Tambah Investasi Rp 4 Triliun di Jombang. Available from: https://surabaya.tribunnews. com/2015/12/17/perusahaan-korea-selatantambah-investasi-rp-4-triliun-di-jombang. Diakses 4 Oktober 2010. 